\title{
THE LEGEND OF THE GOOD FELLA MISSUS
}

\author{
M.E. McGuire
}

The dominant historical myth about the relation between white women and Aborigines portrays the former as kind mistresses and the latter as objects of their maternal care. This paper attempts to retrieve and evaluate what white women could see, speak and know of Aborigines - and especially the images through which white women represented their contact with Aborigines and Aboriginal Australia - in the century before World War Two. Although the 'good fella missus' has a number of faces, individual struggles and differences are less important to this analysis than the power and persistence of the myth. The good fella missus is a pioneer outfacing Aboriginal hostility, and bringing succour to their destitution. She is the missionary seeking salvation for her black brethren. She tends the sick, clothes the naked, and soothes the dying. She is also the literary woman enshrining herself in a position of benevolence and authority in race relations. She has sisters in the other colonies of the British Empire such as the memsahibs of India. She enters the annals of Australian history at about the time that Victoria came to the throne - a monarch who herself evolved into the imperial mother - cultivating an interest in the solicitude for her far-flung native subjects. In the democratic sphere a similar role was assumed by that symbol of service, Florence Nightingale. ${ }^{1}$

The conventions of the myth were modified and renewed from generation to generation. The process began with the emigrant gentlewoman, the pioneer's wife who acclimatised to all that was strange and new in the antipodes. She was succeeded by 'Australia's daughter', whose girlhood friends were Aborigines and who, as a dutiful child and mistress, fulfilled her obligations to those less fortunate than herself. Australia's daughter gives way in her turn to the modern urban woman of the twentieth century who ventures into unknown Australia as writer, artist or anthropologist. The legend of the good fella missus is a gender myth. In all her manifestations, the contours that bind her are the same: goodness, natural or Christian piety, and female authority. The name missus indicates her position as mistress of servants, herself one rung below the master. It is also a nationalist myth: the good fella missus is always a bushwoman, finely attuned to the outback environment that is so alien to the imperial metropolis, and, increasingly, to the Australian city. The colloquial, creolised irregularity of the title 'good fella missus' - popularised in the nineteenth century - itself enshrines a nationalistic impulse. This figure is a constant presence in the violent history of race relations in the nineteenth and twentieth centuries, but her presence has largely been censored.

First generation: The colonial mother

The records of culture contact that we have are those left, for the most part, by

Margaret McGuire is an art historian currently working on a PhD thesis, White women black society 1840-1950'.

1 Florence Nightingale, in a copy of a 'Form of return sent from England to His Excellency the Governor of Westem Australia in 1860, to shew, firstly, the sickness and mortality in schools attended by native children, and secondly, the diseases for which the natives are admitted into colonial hospitals'. Mitchell Library MS 1358A. 


\section{THE LEGEND OF THE GOOD FELLA MISSUS}

gentlewomen. Surveying the surviving nineteenth-century verbal and visual images of Aborigines, one is startled firstly by how much these women wrote. Surfacing in letters, journals, emigrant guides, fiction, cookery books, local histories, memoirs, travellers' tales, and religious tracts, the cumulative effect of their Aboriginal anecdotes is remarkable. In all, the good fella missus is the central subject. Aborigines and Aboriginality reflect her desires and fears. The images that occur most frequently are gynaecological, sexual and mortuary. The second thing one notices is how rarely the gentlewoman drew or painted Aboriginal subjects. The large imbalance between verbal and visual material alerts us both to the strength of the literary tradition which women could tap, and to the taboos against what gentlewomen could see for themselves. These taboos were physically expressed in the spatial boundaries established by class, race and gender.

The relationship of gentlewomen to colonial society was shaped by the ways in which its white segment protected and exploited them. ${ }^{2}$ The good fella missus was always, in fact or in fiction, a mother: motherhood confers authority on the colonial woman, licensing her to speak. She has her children gathered about her within the sanctuary of her home. A window might disclose a scene of wild beauty, but inside all is gracious tranquillity. She is tutor to her children. From her they learn the rudiments of botany and ethnography. From her they hear tales of empire in colonial and familial histories. It is evening - that time cherished by Victorian gentlefolk for reflection and intercourse - when she gathers her children around her to teach them stories. They meet about the hearth, country symbol of domestic comfort. The flickering fire throws into relief the tales of travel and adventure, of suffering and savagery - always in contrast to their own intimate and felicitous selfenclosure. The archetypal erudite mother figure appears in 1841 in the first book published for Australian children; her emblematic significance was established by its title, A mother's offering to her children. ${ }^{3}$ Female status was defined by the amount of protection afforded by the husbands, fathers and brothers who mediated between the exterior world and that domestic interior inhabited by women and children. As witnesses to the violence against the Aboriginal nation, they were protected by self-interest and ethnocentricity.

They knew about the natives before they ever emigrated. Aborigines had entered the colonial world naked. Their natural environment was conceived as one of sex, sinfulness, discomfort and dirt. Nakedness, the symbol in impurity in social life, was associated not only with sexual invitation and transgression, but also with the pollution of dirt, the tyranny of poverty, and the absence of religion - each an affront to British notions of propriety and progress. When Botany Bay was still a penal settlement the convict Margaret Catchpole could confess candidly in a letter home of her inability to know how to look at them, such poor naked creatures'. Catchpole can express pity and bewilderment because she is safe in her master's house when Aborigines visit: 'They behave themselves well enough when they come into our house for if not we would get them punished'. Even though she cannot look at them, she says, 'I for my part, I do not like them'. She knows of the Aborigines only from hearsay - for example, outside the town 'they are very saucy for they always carry with them spears and tommyhawks so that when they can meet with a white man they will rob them and spear them'. 4 The shelter and sanctity of homestead life is opposed to the wilds of Aboriginality. Inside versus outside is the primary spatial opposition used to separate the domesticated domain of white women and the imaginary

Alford 1984.

Barton 1979.

4 Catchpole quoted in Heney: 24. 


\section{ABORIGINAL HISTORY 1990 14:2}

savage life of Aborigines. On the outskirts of settlements would be found the boundary posts beyond which no Aborigines could proceed unclothed or after nightfall. The division of time between night and day equated to the difference between productivity and dissipation. In the country, the fences around the home paddock served the same function, and night time was blackfellow time. These differences of costume, time, and space clothed and naked, day and night, inside and outside - represent the property-based and propriety-bound codes ensnaring the vision of gentlewomen. The absence of stable signs of domestic comfort - a fitful open fire instead of the blazing white-washed hearth - in Aboriginal life underpinned these women's own supremacy. They enter the annals of Australian history as the vessels of civilisation.

By the 1840 s there was a ready market for Aboriginal subjects. There was a vogue in the newspapers for verse lamentations about the Aborigines which revived the $u b i$ sunt (where are they now?) theme employed in mediaeval Latin poetry to celebrate the deeds of the dead and gone. The mother's lament and a call for Christian justice were heard loudest during the nineteenth century in Harriet Beecher Stowe's Uncle Tom's cabin (1852). Importantly, this novel was not about American aborigines, but about African slaves who, unlike the Indians, could attain freedom in British Canada. Stowe's concerns had been anticipated in Eliza Dunlop's poem of 1838, The Aboriginal mother, later set to music by the ubiquitous Isaac Nathan, whose daughter's rendition of the song brought tears to the eyes of her audience. 5

Mrs Dunlop found her sources in newspaper reports of the Myall Creek massacre and in drawing room conversation. An Aboriginal woman had survived the massacre. In the poem Dunlop places a babe in this woman's arms and writes in the voice of the bereft mother. This is the colonial female voice of the nineteenth century: the mother speaking to her child. Dunlop's heroine has all the noble virtues of a wife and mother, namely love and devotion, and all the physical weakness and ignorance of woman. Who will lead them now?, Dunlop asks,

Now who will teach thee, dearest,

To poise the shield, and spear,

To wield the koopin, or to throw

The boomerring, void of fear;

To breast the river in its might;

The mountain tracks to tread?

The echoes of my homeless heart

Reply - the dead, the dead!

The ode erects its neoclassical order out of the incipient disorder of deeds of blood, and finds resolution in a Christian God. It is the poet who brings the blacks' cry of murder to Him, and this, in the myth of the good fella missus, is what matters: the implicit idealisation of the relationship between sterling mother and Aborigine. She is next to God in the house of good government. When Mrs Dunlop's poem was attacked by the Sydney press, ostensibly because her heroine sounded too much like a North American Indian, Dunlop replied that her object was 'awakening the sympathies of the English nation for a people rendered desperate and revengeful by continued acts of outrage'. She makes it plain that her authority derives from her gender, denouncing attempts to 'shade with ridicule ties stronger than death, which bind the heart of woman, be she Christian or savage'. 6 The form of the poem provides more evidence about how gentlewomen could see the other, the alien. Dunlop uses

6 Dunlop quoted in De Sallis 1967:103-105. 
two literary conventions, neoclassical and Gothic. Just as the poet reconciles Aboriginality with motherhood, the grisly murders and fires (the excesses of the Gothic mode) are restrained by the measured formal progression of the dirge. These already stereotyped conventions, one of harmony and balance, the other of fear and danger, are mirror images of each other. Holding the mirror is a gentlewoman.

Visual images by women also obey the prevailing conventions. In the 1820 s Augustus Earle painted urban Aboriginal portraits and drew Aboriginal caricatures for what was a popular market throughout the British Empire. Until the late 1840 s, von Guerard and Glover enlivened their sublime and picturesque landscapes with Aboriginal figures. These three visual conventions - the portrait, the cartoon, and the romance - were the dominant means for representing Aboriginality in art. ${ }^{7}$ In addition there was historical and ethnographic documentation. Nineteenth-century women worked in all these genres, but there is no female equivalent to Earle or von Guerard - or at least not with the same professional status.

The paintings we do have show that Aborigines could be drawn only in formal social gatherings or, equally formally, as part of the landscape. The latter convention is very much in the ascendant, and the Aboriginal figures invariably appear in miniature in the middle or far distance. This can begin to be explained by the taboo against nakedness which prohibited female artists from drawing the human figure from life, and wives from seeing their husbands naked below the waist. To date I have found only one watercolour that deals exclusively with racial violence. In the 1820 s Mrs Collett sketched a hunting scene near Port Macquarie. The dismounted rider (Mitchell Library) shows a spreading landscape. Two figures struggle in the foreground: framed by a tree and thrown into relief against the landscape, a dismounted soldier wrestles with a wild Aborigine. In the far distance an officer on horseback pursues a naked running figure bent close to the ground. The men in the foreground enact the struggle between Jacob and the Angel, those in the background, a hunting scene borrowed from the sport of gentlemen. Mrs Collett's reliance on biblical and neoclassical motifs betrays an inability to represent the reality of violence.

I have found only two sketches depicting Aborigines as part - a peripheral part - of the white social world. These watercolours record the gubernatorial festivities celebrating the monarch's birthday in 1838. Martha Berkeley's The first dinner given to Aborigines (Art Gallery of South Australia) and Mary Stephen's Feast given to the natives by Governor Gawler (Mitchell Library) have many elements in common. Governor Gawler and his guests have moved out of the hall of residence into the landscape where the Protector of Aborigines has assembled his charges. ${ }^{8}$ A dozen gentlewomen are among the spectators, witnesses to the charity of government and its attempts to assuage and domesticate the Aborigines. Mary Stephen depicts the gentlewomen standing with their backs to us in voluminous clothes and bonnets. The Governor, with his uniform and cockaded hat, stands with an aide in the centre of the gathering, the circle completed by a crescent of draped Aboriginal figures. Excluded from this circle en fete, a wild Aborigine with feathers in his hair and paintings on his body sits chained in the foreground shadows. The coercion of this recalcitrant outsider makes perfectly plain the conditions of entry for Aborigines into polite society.

Rendering the savage as an animating part of the grand landscape was a tradition in professional painting reaching back to the seventeenth century. As a genre, it survived in

7 The most useful general survey of early visual representations of Aborigines is I. and T. Donaldson 1985.

8

Watts 1890:82-83. 


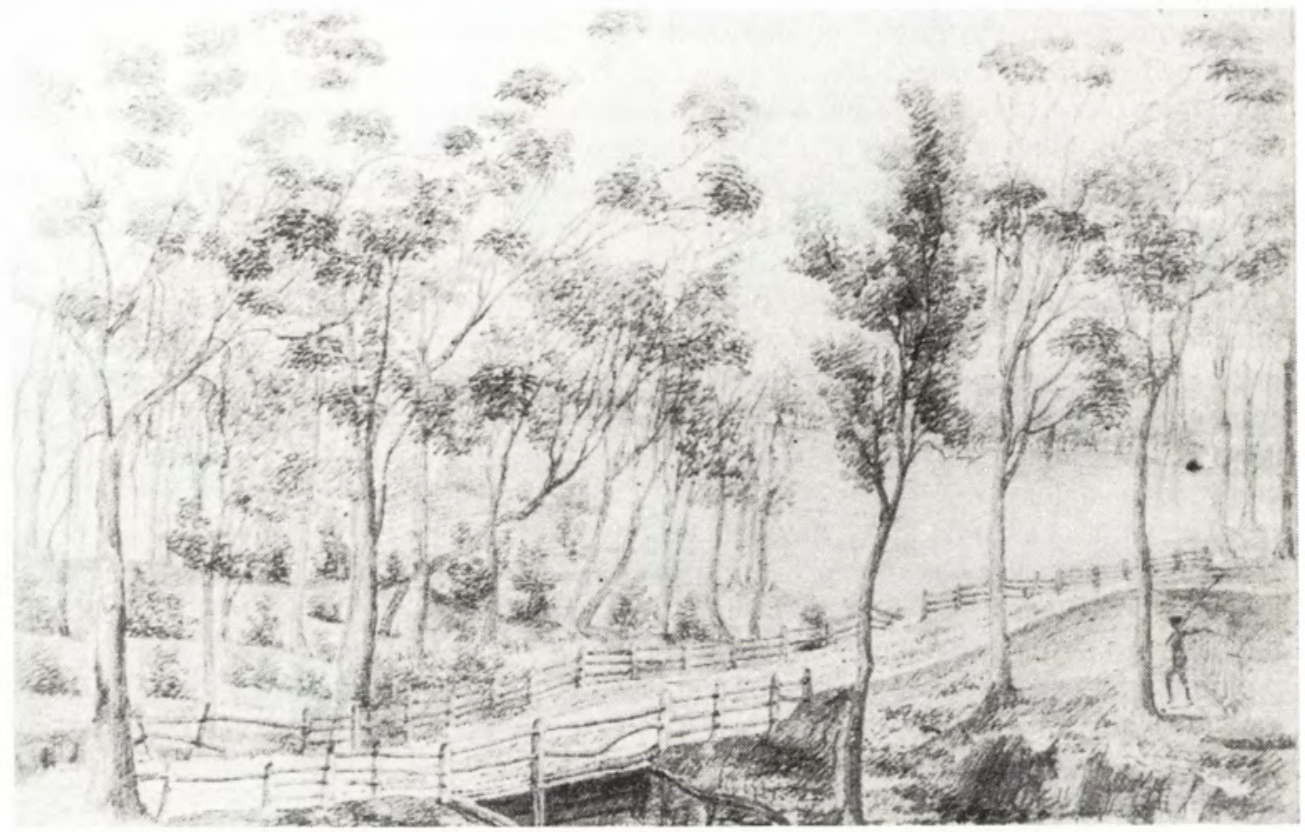

Emily Manning, Ironbarks, 1838 (Mitchell Library)

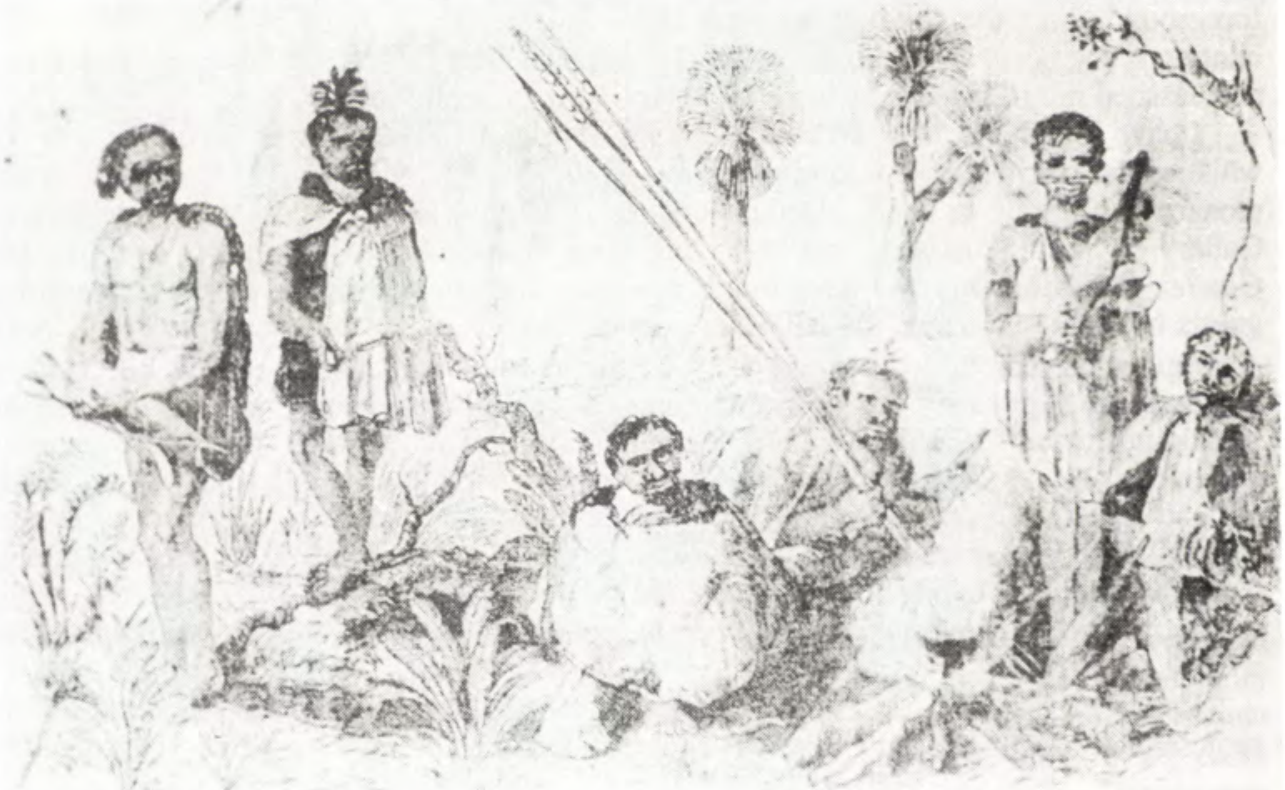

Mrs George King, A group of Swan River natives, 1842 (Society for the Propagation of the Gospel in Foreign Parts) 
THE LEGEND OF THE GOOD FELLA MISSUS

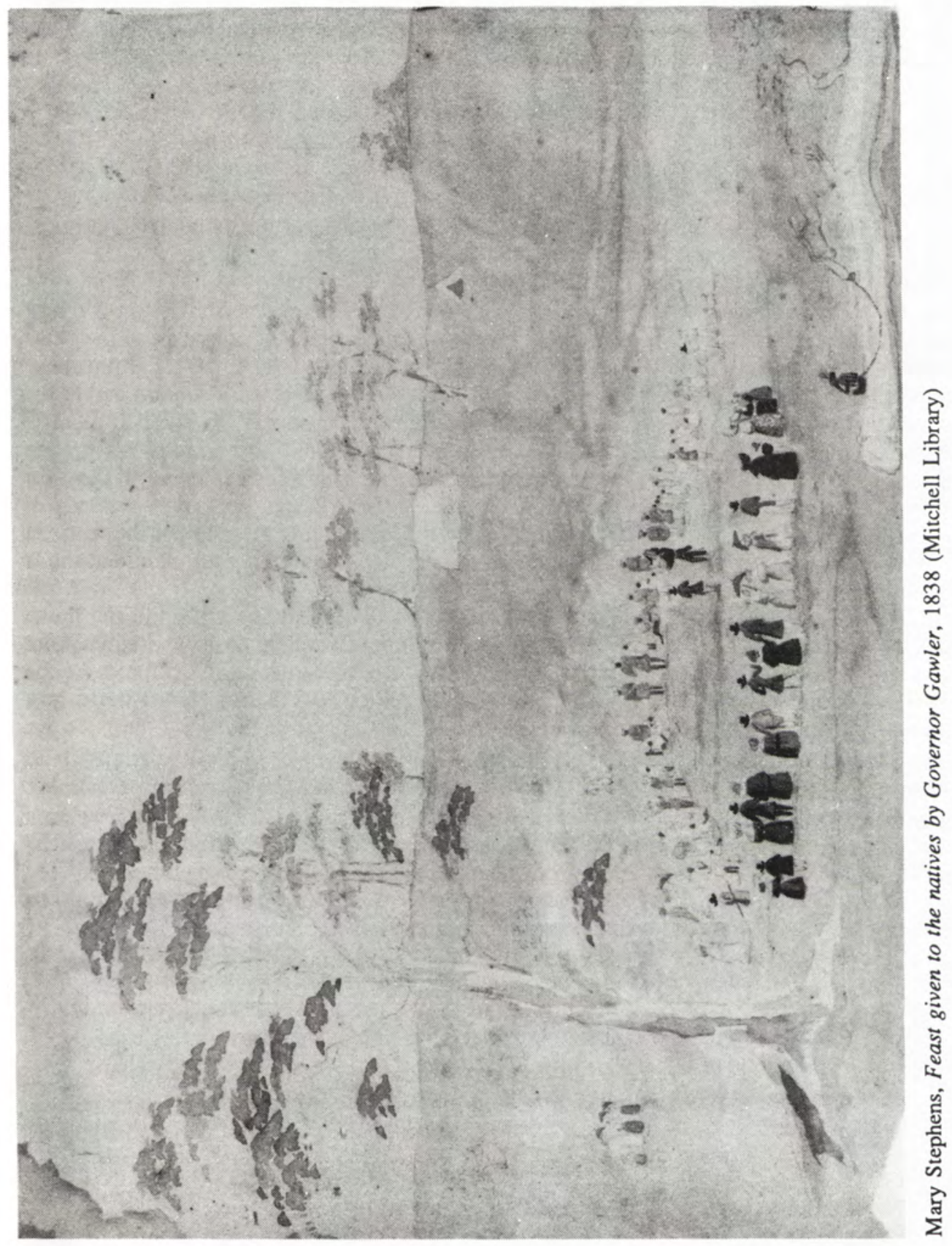


Australia well into the nineteenth century. How much it was a European habit is demonstrated in the work of 'Australia's first woman artist', Sophia Campbell. ${ }^{9}$ She painted the Five Islands off Wollongong with lightning striking over the Pacific and silhouettes of gesticulating Aborigines on the distant hills. This pictorial convention was part of the colonial woman's imagination. Eliza Brown, in her Narrative of a journey (1851) in Western Australia, wrote,

there were some places that presented a grand looking picture to the eye; forests of banksia trees; the sun lighting up the gorgeous transparent flowers, for the most part of a rich orange colour; others lilac, and some white, were sometimes seen below us, in a valley wending between rugged hills. It only wanted a party of natives uttering their wild shouts and poising their quivering spears to give animation to the wild landscape...

'However', she adds, 'we were quite contented that the picture had not this finishing touch. ${ }^{10}$ This use of humour to deflect the fearful is highly characteristic.

Once their travels were behind them, gentlewomen sketched the landscape of their new homes. Aborigines and any sign of Aboriginality are normally excluded from these pastorales. This convention belongs equally to the colonial nineteenth century and to the domestic discourse of women. Emily Manning's sketchbook, now in the Mitchell Library, is representative. It begins with sketches from her sea voyage, and of the sea's strange creatures. Back on land, she sketches from her window. One pencil drawing, Ironbarks, shows, from this elevated perspective, a fenced road and bridge between the stands of eucalypts. It takes a moment to discern under the trees the figure of a tribesman. In rendering Aborigines as part of the landscape the gentlewoman makes it plain that she is culture, they nature.

Part of the legend of the good fella missus is that she travels beyond the home paddocks seeking out the novelty and strangeness of the Australian bush. The lady's point of view' was regarded as a legitimate and refreshing perspective on the colonies by the 1840s. Louisa Meredith's Notes and sketches of New South Wales (1844) is the best known and most quoted traveller's tale, but it was only one of a number, always anonymous but gender-specific. 11 Unlike Louisa Meredith, whose relationship to Aboriginal society was that of the 'imperial prude', Ellen MacPherson represents her relationship to the Aboriginal world as personal and felicitous. ${ }^{12}$ We take up MacPherson's text, My experience in Australia (1860), at the point where she moves from the homestead to the creek: 'One of the most interesting features of the landscape in the vicinity of our station was an encampment of aborigines, about a quarter of a mile from our cottage. The distance between the author and her subject is negotiated by her husband:

I was naturally very anxious to learn all I could about this strange race, and their encampment was a source of great interest to me. It used to be a very favourite resort of ours in the evenings, and my husband would get into conversation with some of the more sociable individuals, and try to extract from them all the information likely to interest me, but they were very chary in communicating anything touching their ways and customs. ${ }^{13}$

\footnotetext{
9 Kerr 1982.

10 Brown in Cowan 1977.

11 Meredith 1973.

12 The phrase is from Foucault 1976:3.

13 MacPherson 1860.
} 


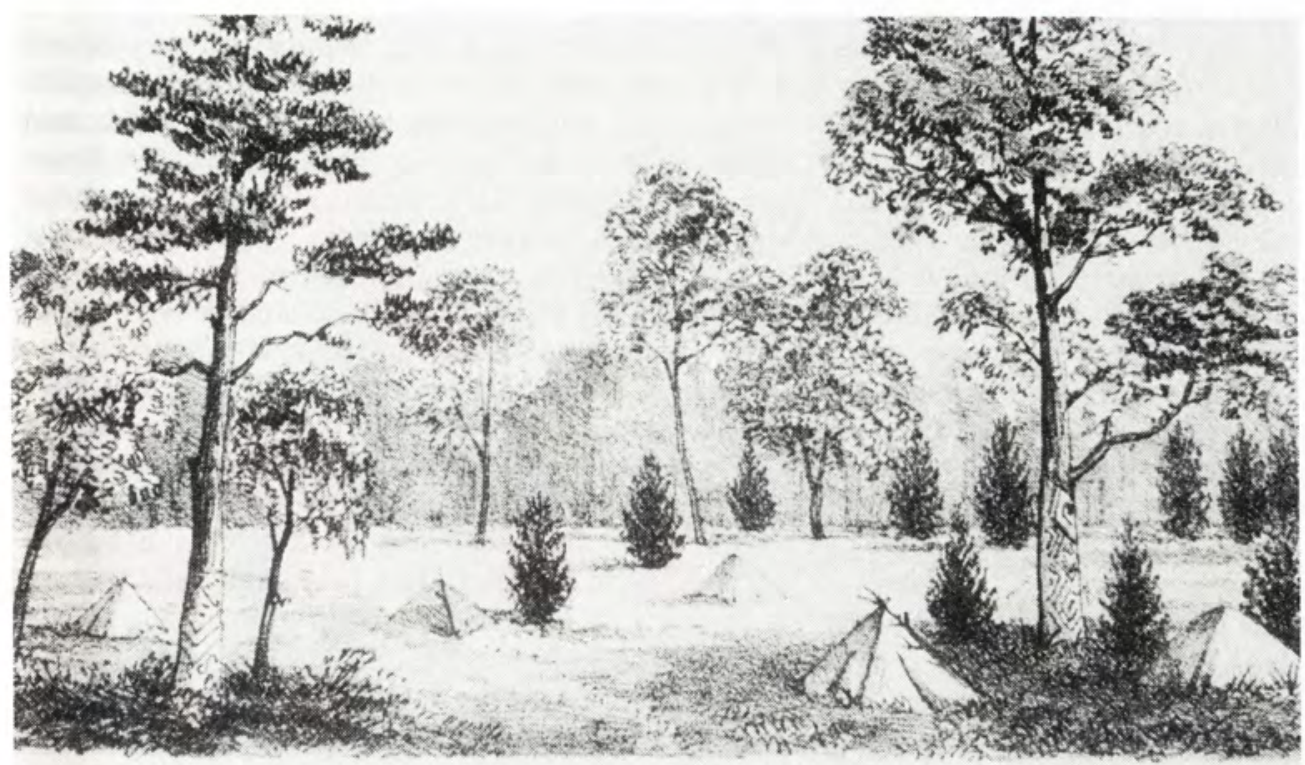

Ellen MacPherson, A native burial place, 1860, from My experiences in Australia.

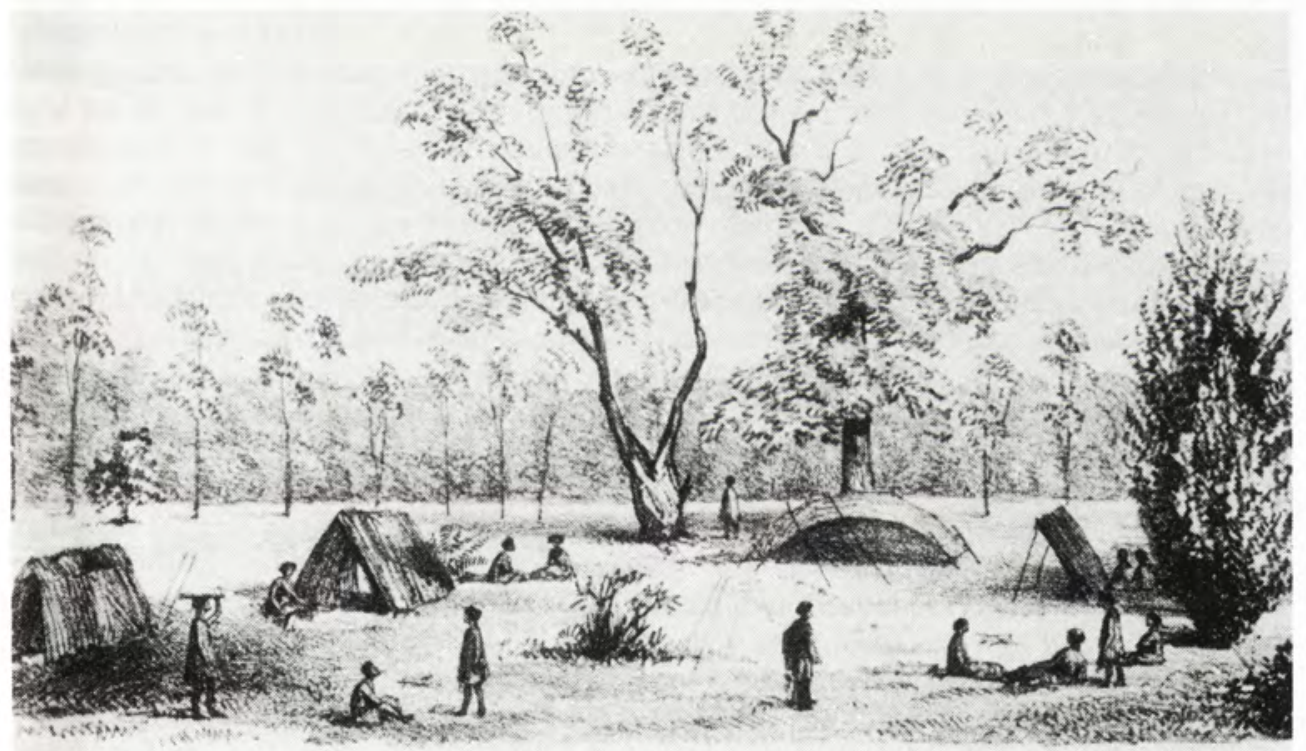

Ellen MacPherson, The Blacks' camp, 1860, from My experiences in Australia. 
Like Louisa Meredith's, MacPherson's information is of two kinds - that received by way of the inter-racial 'patois' from her husband's enquiries, and that received by way of her husband's accounts of his earlier history as a pioneer in the north, tales of hair's-breadth escapes and gruesome murders. The things likely to interest her are also of two kinds, and reflect conflicting desires. She seeks ethnographic evidence of Aboriginal culture - the desire to penetrate mystery; and evidence to disprove Aboriginal claims to the land - the desire for self-justification. She writes both as scientist and squatter's wife.

Back home in Scotland, MacPherson's sketches were engraved as illustrations to accompany her text. Discussion of Aboriginal ways and customs is isolated in two central, detachable chapters (as it was in Meredith's Notes and sketches). MacPherson supplements her discussion with a sketch of the Aboriginal encampment, and a sketch of one of their mysteries, a burial place. In order to depict her relationship to the Aboriginal world affirmatively, she creates an Arcadia. The wilderness has turned out to be a land of trees, plains and running water, full of flora and fauna which she describes at length and with 'intense enjoyment'. The setting of the encampment is rendered like a gentleman's park. (The colonists found land that had been kept clear by Aborigines for hunting and pasture with groups of trees and bushes left standing at intervals, and the comparison with a gentleman's park was a common one.) ${ }^{14}$ The encampment is seen whole in the middle distance on the flat adjoining the creek. The camp is a theatre with a backdrop of forest. The central focus is provided by tall trees which do not begin to branch, as MacPherson noted in her text, until many feet above the ground. Setting the scene are her 'dark friends', moving about in preparation for evening, squatting by fires and reclining in conversation. They are draped in simple shifts. Their shelters are carefully observed in an arrangement whereby they face in much the same direction but from discrete positions. Against the landscape, the Aborigines look like so many Gullivers in Brobdingnag. To MacPherson they remained properly in the landscape, they made such unsatisfactory servants: they preferred their life of 'dolce far niente to the working hours of the farmer' [sic]. The Aborigines were continually moving their habitation, and what she cannot sketch is the transience of their encampment. Her neoclassical rendering of the scene necessarily gives it stability; it is only in her text that MacPherson gives voice to her repugnance against the instability and impermanence she sees in Aboriginal life. Their peripatetic behaviour underlines their shiftlessness and unpredictability. Writing in a Scottish winter, she prefers to see them in the middle distance, draped in a red blanket for a touch of romance amid the grey-green trees.

MacPherson attributes the Aborigines' presence to the liberality of her husband, not to their claim that the property was 'their tourai, the little domain which belonged to them and they to it'. Her husband can speak with them in the jargon she describes as a kind of prison slang. A lady does not deign to make herself understood to foreigners' like Mrs Plomish in Little Dorrit. MacPherson notes the Aboriginal resistance to her husband's process of extracting information. She finds them most resistant to discussing death. Her second sketch, of a burial place, represents her triumph:

They have a great dislike to hear death spoken of, or the names of their deceased friends mentioned. Not far from our station was one of their burial places, and as I was anxious to visit it, after one or two ineffectual attempts to find it by ourselves, we repaired to our friend 'King Sandy', and asked him to direct us to the spot. He shuddered and literally turned pale when we broached the subject, and when we pressed it said in a low tone: No, no, too much dibble, dibble, sit down there'.

14 See, for example, the pioneer writings in [anon]. 1936. 


\section{THE LEGEND OF THE GOOD FELLA MISSUS}

Her husband prevails on 'one more valiant than the rest' to conduct them in the right direction. As they approached this 'terrible spot' their guide departs 'like an arrow': 'We walked on to the place indicated, and under the spreading branches of a monster cypress pine, the first of these graves met our view'. In MacPherson's illustration the view is dominated by eucalypts dwarfing the cypresses and the burial mounds beneath them. The composition is carefully observed with the mounds aligned in their separate positions and with carvings on the gum trunks adding authenticity to a scene without human figures. Again her prospect is from the middle distance and a band of distant forest completes the scene.

I could not but remark the fitness with which they had chosen the site of their cemetery, under the shadow of the gray ironbark, and the sombre cypress pine - a spot that nature seemed to have planted for such a purpose.

In MacPherson's text the Aborigines are circumscribed and dictated to by nature bountiful. She moves closer to examine the carvings, 'rude representations of weapons, such as the boomerang, waddy, etc., and others supposed to delineate opossums and other kinds of game'. These 'hieroglyphics' are the closest approach she can find to literacy: 'they have no written alphabet, nor indeed any means of recording past events'. With no records, no history, the basis of their land claims must be doubtful. The culture of the dead can be read like that of ancient Egypt and, like ancient Egypt, safely consigned to the past. Graves and burials are amongst the commonest Aboriginal subjects. One could sit alone and draw them, like a lady on her Grand Tour sketching the ruins of Rome. The burial place becomes a symbol not of native customs, but of the extinction of the race. MacPherson undercuts the conventional elegaic mood of Romanticism by conjuring up frontier stereotypes of savagery. In the north Aborigines exposed their dead in the trees. In the north they feast on the dead. As in all such travellers' tales, her savage imagery culminates in Gothic descriptions of the corroboree. Naturally she sees one for herself, and can only compare the 'scene of wild diablerie' to German dramas in which the leading players have sold their souls to the devil.

A distinctive narrative persona emerges from these popular memoirs by emigrant gentlewomen of the mid-nineteenth century. When they ventured into print it was invariably with protestations of verisimilitude. They emerged from their world of domesticity in the hope of enlightening and amusing their readers. The autobiographical self is subordinate to the exposition of her subject, life in the colonies. She is the squatter's wife and it is civilisation that kills the native.

Besides MacPherson's two sketches, I have found only one other published image attributed to a woman. In 1864 a sketch by Mrs King appeared as an illustration in a missionary journal. Here she lines up a group of male Aborigines to display their physiognomies, costumes and weapons in an attempt to illustrate each season and ceremony in their forms of dress. She is exemplifying what must be learnt about Aborigines in order to accommodate and redeem their ways and customs within the Christian code. The assumption is plain: one need only know and control the men. ${ }^{15}$

The most public and independent vessel of civilisation in the 1840 s was Caroline Chisholm. Her writings, soliciting the emigration of young women, demonstrate the prevailing preoccupation with native welfare and native rights, made more pressing in Australia by the publicity given to racial violence. Her writings illustrate how gentlewomen could make what use they wanted of the Aborigines: Chisholm uses the

15 Mrs George King, 'A group of Swan River natives', in Society for the Propagation of the Gospel in Foreign Parts, Quarterly Paper, xxxiii, April 1845. 


\section{ABORIGINAL HISTORY $1990 \quad 14: 2$}

unholy reputation of the Australian colonists as a finger on the sore of the contemporary conscience. She follows the convention of the lament over the passing of the tribes, a convention traceable in women's writing to the seventeenth century and Aphra Behn's Oroonoko (1678). In her Prospectus of 1845, Chisholm's stated ambition is to break up the Bachelors' Stations' with a leaven of two thousand young women of good character:

If the happiness of her own children does not induce England to adopt prompt measures to secure this blessing to the Colony, the gradual destruction and extermination of the aborigines demand it from her justice! 16

This rhetorical rendering of the theme of parent and child makes no connection between the settlers' and the Aborigines' lives. It is only in private, in a letter to the Secretary for the Colonies, Earl Grey, that she can allude to the sexual exploitation of Aboriginal women by bachelors and squatters. The 'frightful' numerical disparity of the (white) sexes is a: crying and national evil from which flows misery and crime, I dare not dwell upon, and to this unnatural anomaly of the human race in that Colony, may be traced in a great degree the gradual but certain extermination of those unfortunate tribes the Aborigines of New Holland; they, the original holders of the soil, demand the speedy and parental interference of a humane Government. ${ }^{17}$

Elsewhere, Chisholm is silent, and makes only one other reference to these original owners. Riding on her white horse on her last inland journey to Bathurst, she has one Edenic glimpse of the Aboriginal world, represented by a group moving through the bush tracking bees with birdsdown. Aborigines had no place in her vision of a productive Arcady of villages and church spires.

It was rare for white women to acknowledge white men's exploitation of black women even, as in Chisholm's case, from motives of expediency. Aboriginal familial life had, by the end of the eighteenth century, been distorted to fit the outlines of Christian marriage. Blake's now famous engraving, A native family, reflects the unilateral symbolic imposition of the form of the bourgeois family. A warrior advances with his weapons, a mother follows with a babe-in-arms and chattels, and behind her comes the future in the figure of a small boy. This engraving appeared in Captain Hunter's Historical journal (1793). The frontispiece in the same volume, engraved by another hand, depicted defenceless, naked, black womanhood under the gaze of officers and gentlemen. ${ }^{18}$ The first picture illustrates the dominance of man, the second, the fertile vulnerability of woman alone. White women lost to Aboriginal society were also imaged in this way. The best known example is Mrs Eliza Fraser of the Sterling Castle; her story is given in A mother's offering, where she is saved by God.

Gentlewomen readily and vigorously agreed that the status of the Aboriginal woman was worse than that of a slave, and that their black husbands were the brutes of creation. Amongst the most common scenarios in the life of the good fella missus is one in which she rescues a trembling and cowering Aboriginal woman from the waddy of her enraged husband. In fact, Aboriginal society presented a mirror image of the gentlewoman's own sexual and economic repression. ${ }^{19}$ The Aboriginal deaths and burials that dominate the white female discourse on Aborigines are equalled in number only by demonstrations that

19 On the oppression of Aboriginal women see Evans 1982 and McGrath 1978. 


\section{THE LEGEND OF THE GOOD FELLA MISSUS}

Aboriginal women are no more than beasts of burden. Aborigines, like the weather, function in narratives as metaphors for the author's sense of being. It is only in extremis that a gentlewoman can see in Aboriginal women her sisters in oppression. 20

In fiction, set-pieces reflecting the gentlewoman's confident belief in the brutishness of Aboriginal women's lives are used to illuminate and comment upon the trials of the heroine. The Australian fictional heroine in the nineteenth century characteristically appears herself - for the nonce - as a social slave aspiring to independence and self-reliance; she is commonly, like Jane Eyre, an orphan and a governess; and the plot turns on how and whom she marries. The heroine encounters Aborigines when she herself is desolate and near-destitute, and the Aborigines or Aboriginality reflect back her desolation and destitution. Catherine Helen Spence's Clara Morrison (1854) is typical. At the lowest point in her career, when Clara the emigrant girl has been forced into service below her station and when she despairs of ever attaining the man she loves, she meets Black Mary, an elderly Aboriginal woman who comes to chop wood, and whose narrative function is to offer a grotesque parody of womanhood and a portent of the terrible fate of old women alone. ${ }^{21}$ Much as the canon of Australian literature would be enriched by the admission of neglected women's writings, it is a mistake to assume that these writings provide an alternative history of race relations. Recent attempts by some feminist critics to suggest that the course of imperial conquest would have run smoother had women been in charge constitute a belated revival of the legend of the Good Fella Missus. ${ }^{22}$

\section{Second generation: Australia's daughter}

Australia's daughter was a fearless bushwoman educated by her sterling mother and the environment in which she grew up. She has a 'natural' relationship to the bush and its creatures. Her parents projected the ideal relationship between settler and savage as a feudal one. She fulfills her obligations to those beneath her. In this guise, she is recognisable in the writer, artist and botanist, Louisa Atkinson. Later in the ninteenth century she is recognisable in the novelist Rosa Praed, whose deployment of Australia's daughter as heroine and the Aborigine as savage in her fiction - not excepting her autobiography, where she writes, 'I love the blacks' - should be notorious. ${ }^{23}$

To date I have located only two homestead portraits that include Aboriginal figures, one by an Australian daughter and the other by an emigrant clergyman's wife. The compositions, one from New South Wales, one from Western Australia, are comparatively close. The first, Ellen Bundock's Yugilbar (c.1850, Mitchell Library), depicts the ideal relationship between settler and savage. The second, Janet Millett's Holy Trinity Church, York, Western Australia (c.1869, private collection), symbolises the clergyman's mission. ${ }^{24}$ In both, Aboriginal figures are cast into the foreground shadows. An analysis of Bundock's picture must suffice here. Ellen Bundock's painting of Yugilbar is in marked contrast to most homestead portraits because she locates Aboriginal figures in the home

20 Annie Baxter provides an example. See Frost 1984:100 and 'Annie Baxter and her journal 1834-68' in Adelaide 1988:38.

21 See Smith 1980.

22 Dale Spender is representative of this trend in Spender 1988: 195-199.

23 Praed 1904:4.

24 Millett 1980. 
unholy reputation of the Australian colonists as a finger on the sore of the contemporary conscience. She follows the convention of the lament over the passing of the tribes, a convention traceable in women's writing to the seventeenth century and Aphra Behn's Oroonoko (1678). In her Prospectus of 1845, Chisholm's stated ambition is 'to break up the Bachelors' Stations' with a leaven of two thousand young women of good character:

If the happiness of her own children does not induce England to adopt prompt measures to secure this blessing to the Colony, the gradual destruction and extermination of the aborigines demand it from her justice! 16

This rhetorical rendering of the theme of parent and child makes no connection between the settlers' and the Aborigines' lives. It is only in private, in a letter to the Secretary for the Colonies, Earl Grey, that she can allude to the sexual exploitation of Aboriginal women by bachelors and squatters. The 'frightful' numerical disparity of the (white) sexes is a: crying and national evil from which flows misery and crime, I dare not dwell upon, and to this unnatural anomaly of the human race in that Colony, may be traced in a great degree the gradual but certain extermination of those unfortunate tribes the Aborigines of New Holland; they, the original holders of the soil, demand the speedy and parental interference of a humane Government. 17

Elsewhere, Chisholm is silent, and makes only one other reference to these original owners. Riding on her white horse on her last inland journey to Bathurst, she has one Edenic glimpse of the Aboriginal world, represented by a group moving through the bush tracking bees with birdsdown. Aborigines had no place in her vision of a productive Arcady of villages and church spires.

It was rare for white women to acknowledge white men's exploitation of black women even, as in Chisholm's case, from motives of expediency. Aboriginal familial life had, by the end of the eighteenth century, been distorted to fit the outlines of Christian marriage. Blake's now famous engraving, A native family, reflects the unilateral symbolic imposition of the form of the bourgeois family. A warrior advances with his weapons, a mother follows with a babe-in-arms and chattels, and behind her comes the future in the figure of a small boy. This engraving appeared in Captain Hunter's Historical journal (1793). The frontispiece in the same volume, engraved by another hand, depicted defenceless, naked, black womanhood under the gaze of officers and gentlemen. ${ }^{18}$ The first picture illustrates the dominance of man, the second, the fertile vulnerability of woman alone. White women lost to Aboriginal society were also imaged in this way. The best known example is Mrs Eliza Fraser of the Sterling Castle; her story is given in A mother's offering, where she is saved by God.

Gentlewomen readily and vigorously agreed that the status of the Aboriginal woman was worse than that of a slave, and that their black husbands were the brutes of creation. Amongst the most common scenarios in the life of the good fella missus is one in which she rescues a trembling and cowering Aboriginal woman from the waddy of her enraged husband. In fact, Aboriginal society presented a mirror image of the gentlewoman's own sexual and economic repression. ${ }^{19}$ The Aboriginal deaths and burials that dominate the white female discourse on Aborigines are equalled in number only by demonstrations that

16 Quoted by Kiddle 1950:83.

17 Ibid:246.

18 Hunter 1968:xxvii, 261. A native family is discussed in Smith 1960.

19 On the oppression of Aboriginal women see Evans 1982 and McGrath 1978. 


\section{THE LEGEND OF THE GOOD FELLA MISSUS}

Aboriginal women are no more than beasts of burden. Aborigines, like the weather, function in narratives as metaphors for the author's sense of being. It is only in extremis that a gentlewoman can see in Aboriginal women her sisters in oppression. ${ }^{20}$

In fiction, set-pieces reflecting the gentlewoman's confident belief in the brutishness of Aboriginal women's lives are used to illuminate and comment upon the trials of the heroine. The Australian fictional heroine in the nineteenth century characteristically appears herself - for the nonce - as a social slave aspiring to independence and self-reliance; she is commonly, like Jane Eyre, an orphan and a governess; and the plot turns on how and whom she marries. The heroine encounters Aborigines when she herself is desolate and near-destitute, and the Aborigines or Aboriginality reflect back her desolation and destitution. Catherine Helen Spence's Clara Morrison (1854) is typical. At the lowest point in her career, when Clara the emigrant girl has been forced into service below her station and when she despairs of ever attaining the man she loves, she meets Black Mary, an elderly Aboriginal woman who comes to chop wood, and whose narrative function is to offer a grotesque parody of womanhood and a portent of the terrible fate of old women alone. ${ }^{21}$ Much as the canon of Australian literature would be enriched by the admission of neglected women's writings, it is a mistake to assume that these writings provide an alternative history of race relations. Recent attempts by some feminist critics to suggest that the course of imperial conquest would have run smoother had women been in charge constitute a belated revival of the legend of the Good Fella Missus. 22

\section{Second generation: Australia's daughter}

Australia's daughter was a fearless bushwoman educated by her sterling mother and the environment in which she grew up. She has a 'natural' relationship to the bush and its creatures. Her parents projected the ideal relationship between settler and savage as a feudal one. She fulfills her obligations to those beneath her. In this guise, she is recognisable in the writer, artist and botanist, Louisa Atkinson. Later in the ninteenth century she is recognisable in the novelist Rosa Praed, whose deployment of Australia's daughter as heroine and the Aborigine as savage in her fiction - not excepting her autobiography, where she writes, 'I love the blacks' - should be notorious. ${ }^{23}$

To date I have located only two homestead portraits that include Aboriginal figures, one by an Australian daughter and the other by an emigrant clergyman's wife. The compositions, one from New South Wales, one from Western Australia, are comparatively close. The first, Ellen Bundock's Yugilbar (c.1850, Mitchell Library), depicts the ideal relationship between settler and savage. The second, Janet Millett's Holy Trinity Church, York, Western Australia (c.1869, private collection), symbolises the clergyman's mission. ${ }^{24}$ In both, Aboriginal figures are cast into the foreground shadows. An analysis of Bundock's picture must suffice here. Ellen Bundock's painting of Yugilbar is in marked contrast to most homestead portraits because she locates Aboriginal figures in the home

20 Annie Baxter provides an example. See Frost 1984:100 and 'Annie Baxter and her joumal 1834-68' in Adelaide 1988:38.

21 See Smith 1980.

22 Dale Spender is representative of this trend in Spender 1988: 195-199.

23 Praed 1904:4.

24 Millett 1980. 


\section{ABORIGINAL HISTORY 1990 14:2}

landscape as part of the rural economy. We need first to sketch in the family history which forms the subtext of the painting. 25

The property at Yugilbar stretched back along a bend in the Clarence River and was established as a sheep run, by Bundock's brothers, in the 1830s. They were the children of William and Mary Ogilvie, pioneer settlers in the Camden district with dynastic aspirations. Establishing themselves as master and mistress to Aboriginal servants meant some adjustment was necessary for the Ogilvies. They endeavoured to learn all they could of Aboriginal ways in order to manipulate power and exercise control more efficaciously and, through Aboriginal knowledge, to subjugate the wilderness more effectively. Learning the local Aboriginal language was a priority. Their son Edward, when he came to tame Yugilbar, acted on the same principles. He first took possession of an Aboriginal boy, Puldoon, to be not only his servant, but his aide and go-between. Later in life, Tom Roberts painted Edward Ogilvie as the gentleman squatter. Later still, Donald Friend painted him wrestling with an Aboriginal warrior in a symbolic trial of strength - an image taken from Ogilvie's memoirs rather than life. ${ }^{26}$

Ellen Bundock did not travel to Yugilbar till some twenty years later, around 1850 . Her journey, with two small children, took on epic proportions in local history: 'the bush held

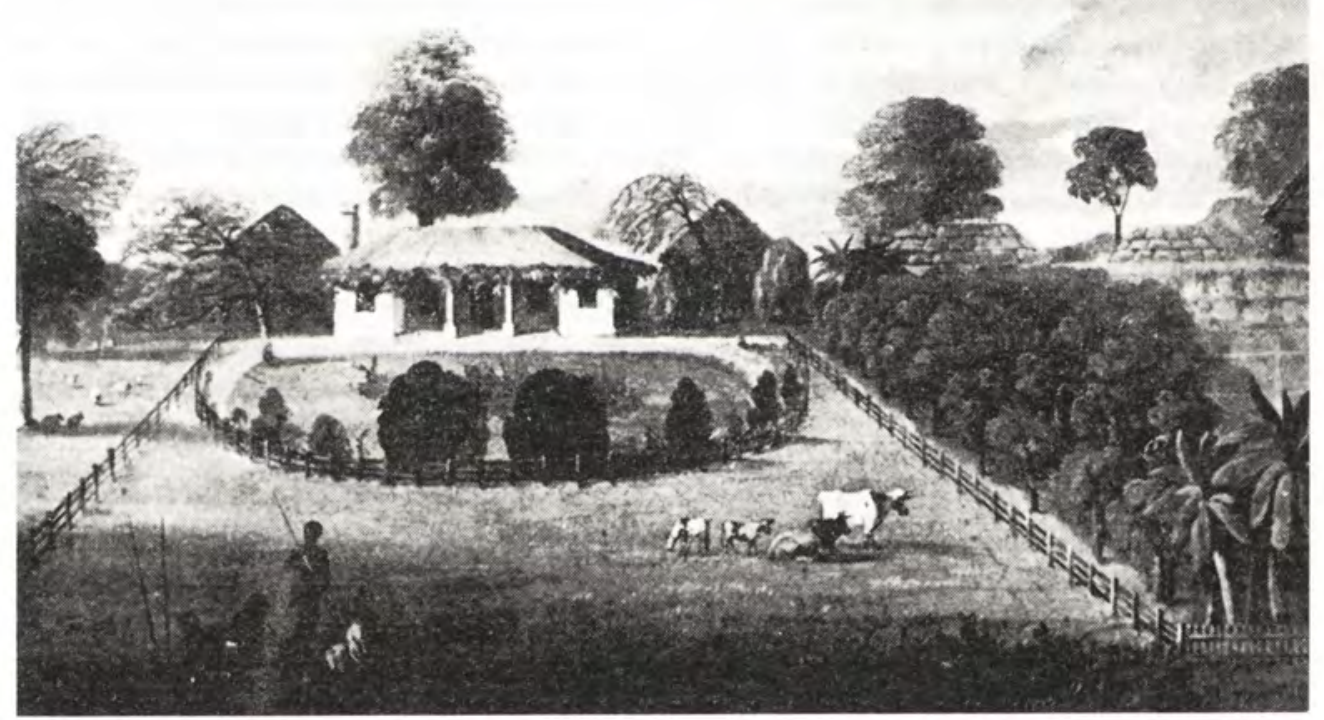

Ellen Bundock, View showing original Yugilbar homestead. c.1850 (Mitchell Library)

25 G. Farwell in McBryde 1978 Murray-Prior 1973.

26 Roberts, Squatter's Castle (1894, Mitchell Library) and Donald Friend, Edward Ogilvie Wrestles with Toolbillibam (date unknown, private collection). Both are reproduced in Farwell 1973. 


\section{THE LEGEND OF THE GOOD FELLA MISSUS}

no fears for her'. ${ }^{27}$ Her mother had the singular distinction of being the only gentlewoman to enter government dispatches for her capable management and good sense in race relations. Mary Ogilvie, through her acquaintance with the local Aborigines, had prevented the wrongful arrest of a black man, and averted any shedding of blood on the Merton property at Camden. The blood, as Govemor Darling noted dolefully, was shed elsewhere. Here again we meet the favoured archetype of the pioneer heroine, with her ameliorating influence on the violence of white settlement. In the local archives the women of the Ogilvie family are credited with a tradition of humanitarian actions and attitudes towards the Aborigines: 'the Ogilvie girls love the blacks'. 28

Ellen Bundock's painting, a watercolour, decorated the lid of a lady's workbox. It commemorates the original Yugilbar cottage. The scene conforms to the pictorial tradition of Arcadian pastoral. The thatched cottage is seen as day draws to an end, nestling in the centre. Veracity, that prime Victorian narrative merit, has been the artist's aim; she is telling the story of daily life. This hybrid, mixing the ideal and the real, gives this unassuming painting its poignancy. The squatter is nowhere to be seen; instead we see the fruits of his labours in the tranquil hour before evening, across the home paddock to the dwelling catching the last of the sun. The neat perspective of the enclosure composes the scene. Outside the fence, to the left, sheep are grazing (they later got foot-rot); on the right, a band of semi-tropical bush trees testifies to the lushness of the river country and to the labour involved in its domestication. A small family of cows, in the English county tradition, is set within the home paddock beneath the ring of an English garden, standing and resting in monumental profile; like the house, they catch the last of the light. Also placed within the enclosure are four Aboriginal shepherds. They hold, in miniature, poses of Greek athletes with spears. Their bodies are draped in blankets, at least one of which is of the ubiquitous red, the preferred colour to place against a dark skin. (In Van Diemen's Land, Thomas Bock painted Lady Franklin's Mathianna in the red dress she favoured for her charge. ${ }^{29}$ The Aborigines shrouded by shadows and the cows in the light presage the future.

Memoirs are written in the first person; as long as they construct a lost past, romance is present. In their recollections, Louisa Atkinson and Mary Bundock - child of Ellen and hence a second-generation Australian daughter - were children at a time when the land still belonged to gentlemen squatters, before 'their' Aborigines were degraded by contact with the lower classes. They themselves are witness to the passing of Aboriginal life. The habit of literacy was one of the marks distinguishing Australia's daughter from others less fortunate than herself; as for her sterling mother, writing was her way of sustaining intellectual life in isolation. Australia's daughter remembers Aborigines as part of her childhood. Unlike the Aborigines, she can tell their stories to an urban audience ignorant of such contact. She maintains a doubly privileged position, in relation to her subject and to her audience. She writes herself as the child of culture sympathetic to the children of nature, the Aborigines. This manifestation of the good fella missus is recognisable in Katherine Langloh Parker translating Aboriginal myths and legends. The writer becomes the heroine. By the second half of the nineteenth century Australia's daughter constituted a tradition, one to which Rose Praed and Mary Gilmore subscribed in the name of Australian nationalism and identity.

Daley 1966:82.

29

Murray-Prior 1973:68.

Bock's painting is reproduced in Dutton 1974 and Thomas 1988. 
James Atkinson cited the journeys he had made into the wilds 'with no other attendants than two Black natives, on whose fidelity I could rely. ${ }^{37}$ His frontispiece is a picture of a white explorer on horseback accompanied by two liveried natives on foot. One of these can be identified from Louisa's 'Recollections' as the Jim Vaugh who had once saved the life of her father. Perhaps the second attendant in James Atkinson's picture is the Aboriginal character who, in his daughter's text, plays the part of Bennelong, the Aborigine corrupted by his contact with white society after the demise of his white master.

Louisa Atkinson tells stories of the loyalty and affection extended to her family by Aborigines because of her father. Apart from his book, and what she heard of him, Louisa never knew him; he had died shortly after she was born in 1834 . Louisa wrote, 'They attach themselves warmly to those who show them kindness, and are ready to exhibit their friendship in various ways'. One such exhibition of friendship happened some six years after her birth, when the Aboriginal friends of James Atkinson came to commiserate with his widow. This anecdote, which is also recorded in A mother's offering, is included ostensibly to illustrate the 'peculiarities' of Aboriginal attitudes to death, especially the burial of the possessions of the dead. ${ }^{38}$ Louisa Atkinson writes,

A gentleman, to whom they were much attached, had died, leaving a widow and young family; a number of natives assembled to visit her, and see the new inmate - born since they had been there last; after gratifying their wish to see all the orphans, the widow exhibited a lock of her deceased husband's hair. Instantly horror and grief siezed upon the party; men and women bowed their heads and wept, till at length one woman approached and whispered, 'Missis neber you show that to black fellow; neber any more'.

Atkinson, like her mother, is careful to render this autobiographical episode anonymous in order to make it representative of the excesses of Aboriginal behaviour in general. The anecdote is important to our reading precisely because of the autobiographical element. She places herself, as the 'new inmate', at the centre. The episode expresses not only the trauma of her father's death, not only her privileged position in relation to the visitors, but also her initiation into Aboriginal Australia. 39

It would require another paper to make a parallel reading of $A$ mother's offering and the 'Recollections'. Such a reading needs to be grounded in its historical context; that is, in the context of the progressive colonisation of the hinterland from Berrima to the Shoalhaven. Suffice it to say that the most important likeness is that they both frame their pictures of Aboriginal society as vignettes drawn from a dying and soon to be extinct race. There are two important differences. In the first place, Atkinson in the $1860 \mathrm{~s}$ is addressing an adult audience which she rightly suspects is mostly hostile to her subject:

It is a matter of course to pronounce them the lowest scale in the human ladder, the last link between man and monkey; a degraded people incapable of improvement; beyond the pale of civilization, and destitute of religion, and recognising only an evil spirit.

The second important difference is how Atkinson goes out into the landscape to make her observations. Where the mother and her brood met the Aborigines as servants and visitors to their homestead, Atkinson desires to study them in nature. She improves on Barton's

\section{7}

38

Atkinson 1975.

Muir 1980:28-29.

39 There are many accounts of the welcome to white children bom in Aboriginal land. See, for example, McCrae 1966:100. 


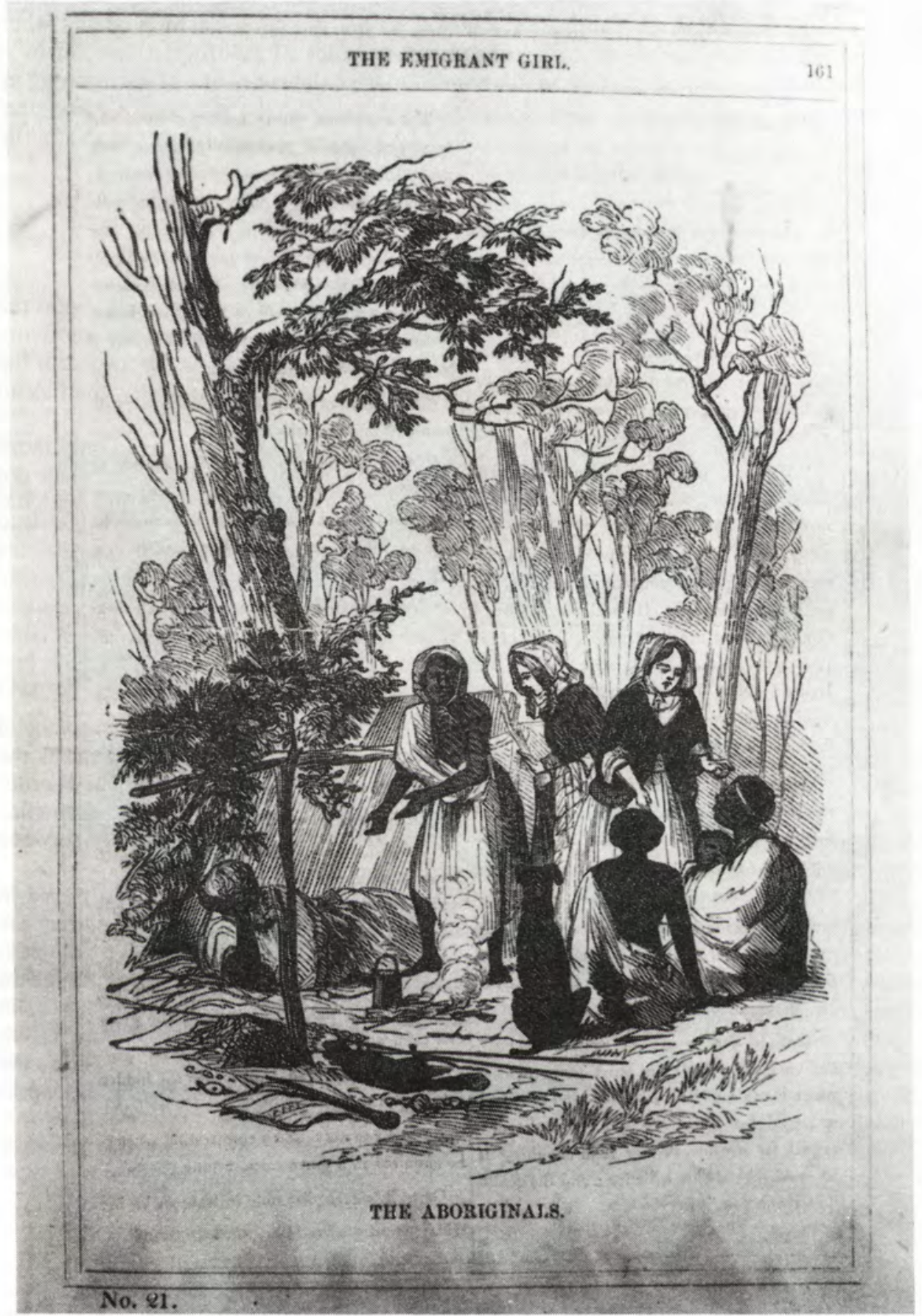

Gertrude and the widow Mrs Doherty bring succour to a dying Aborigine, 1857, probably engraved from a drawing by Louisa Atkinson (from Gertrude the emigrant girl) 


\section{ABORIGINAL HISTORY 1990 14:2}

example in adopting the tools of natural history to identify and classify Aboriginal customs. An instance of the daughter advancing on her mother's teaching occurs when Atkinson returns to Berrima to verify and measure relics of Aboriginal culture. In $A$ mother's offering, a medical gentleman had wanted to have the bones of a black man dug up from a nearby burial site, an incident included to demonstrate the strength of Aboriginal superstition. This request is refused. In the 'Recollections', Atkinson returns to this burial place. She discovers the grave to be one hundred by forty feet,

of a gentle conical form, covered with herbage, and surrounded at its base with trees, which, on their sides fronting the mound, were carved in forms suggesting the native shield and boomerang - weapons used chiefly in war.

There could be little doubt but that the tumuli is all, or in part, artificial...

Because 'the blacks cannot, or will not give any information', Atkinson can only report the speculation that the flat below was the scene of a great battle, and that the survivors assembled to bury the dead and mark the site. This mediaeval fancy is contrasted to the present time when Aborigines 'neglect the carving of the trees ${ }^{t}$ and bury their dead expeditiously in anthills.

In her attempts to identify and translate social systems, Atkinson can read only those signs that show order, discretion and good management. Most of her studies were made not at Berrima, but at the Shoalhaven, where her widowed mother had sought refuge with her children from a hostile world. Here Atkinson was witness to a festival.

One one occasion, when the remnants of three different friendly tribes had assembled for a grand corroboree or dance, I made a plan of the encampment; each tribe was slightly apart from the other, divided by a sort of street. Thus, the inviters were clustered in the centre, having, I think, seventeen camps; the Picton tribe on the right hand, five camps; and the Shoalhaven on the left, comprising ten or eleven gunyahs; consecutively forming a village.

She noted that though their dwellings might be close together, 'yet each was so arranged that its open side was turned from its neighbours'. What she cannot comprehend is the temporary nature of an otherwise excellent arrangement. To her mind, the dirt and disorder of the campsite, with its 'May Fair scatterings of rags...conspire to make change desirable'. The analogy of the camp to a village breaks down. There can be no conformity between stability and hygiene and impermanence and dirt.

The legal and social position of widows and single women is a dominant theme in Louisa Atkinson's fiction. Her first novel, Gertrude the emigrant girl (1857), initiates the central subject of Australian fiction from a woman's point of view for most of the next century. What Atkinson writes in the 'Recollections', not of Aboriginal marriage in general, but of one particular Aboriginal marriage, is shaped partly by her mother's trials in the white world. Among Jim Vaugh's wives was one Nelly, who had removed herself from her husband to live on a low island in the river with a female companion. Nelly claims the land 'all about' to be her own. The two women had a canoe and 'appeared to support themselves by fishing':

It was but necessary to mention Nelly to the chief to arouse the savage in him; then he would swear, stamp his feet on the ground, yell and threaten her with instant death...

If these threats of Jim Vaugh were repeated to Nelly, they produced the most extravagant laughter and enjoyment; she would beg again and again to have the piquant scene rehearsed, at each time clapping her hands, dancing, shrieking, and laughing in all the extravagance of savage mirth. Her enjoyment was shared in a lesser degree by the little blind dame. 


\section{THE LEGEND OF THE GOOD FELLA MISSUS}

The savage extravagance of the couple's behaviour in this role reversal is a burlesque upon her own mother's powerlessness after the death of James Atkinson. Certainly this tale contradicts Louisa Atkinson's generalisations about Aboriginal domestic relationships, in which the men are the lords and masters of all women.

What white women wrote of Aborigines was a reflection of their own circumstances. Who knows, for instance, whether Langloh Parker would have taken such an interest in the 'Noongahdburrah' people had she not been lonely and childless, and had she not been saved from drowning in childhood by an Aboriginal servant; It is surely significant that the white women who made ethnographic and anthropological studies of Aboriginal society were themselves childless and usually spinsters.

\section{Third generation: The modern woman}

With the end of the Victorian era, the generation of rural daughters gives way to the young urban women who become the professional writers, artists and anthropologists of the twentieth century. Like the sterling emigrant gentlewomen, they too have to make a journey to find Aboriginal subjects in central and northern Australia, and their writings too take on the dimensions of adventure and romance in uncharted country.

In fiction, the good fella missus was further popularised in the first decade of the century by Jeannie Gunn's The little black princess (1905). Besides the myth of her husband as the good Maluka, we find the usual colonial traditions; the mother weaving stories for her children and the kindly white mistress who adopts and trains an Aboriginal 'orphan'. All that has changed is the setting, from the bush to the never-never. The 'little missus' of The little black princess walks out into the landscape with her Bett-Bett and older Aboriginal women. From them she leams the names and habits of the bounteous flora and fauna in the rich country of the Roper River. Baldwin Spencer, who reviewed this, Gunn's first book, is one in a line of male anthropologists who enthused about the contribution white women could make to a fuller understanding of Aboriginal life:

On her lonely station in the Never-Never Country, with no white woman within a distance of a hundred miles, Mrs Gunn, the 'good-fellow missus' of the homestead, lived amongst and learned to know the natives. The result is seen in this little book, with its glimpses of native life, such as we have never had before. 40

In the 1930s, Elkin called upon 'the wives and daughters of station managers, settlers and officials to carry on the work of Mrs Langloh Parker and Mrs Aeneas Gunn and depict for us the life of the native women and children'. ${ }^{41}$ While it is for male anthropologists to pursue the serious business of the religious rules and social regulations of Aboriginal society, the proper study of woman is woman: 'the women's life, and that part of men's life which is passed with the women and children, reveal the essential and natural humanity of the Aborigines'. Elkin, introducing Phyllis Kaberry's Aboriginal woman, sacred and profane (1939), continued: 'The male anthropologist is apt to feel, and rightly so, that he as a man should respect the taboo and not pry into the preserves of the other sex'. There is not a little prurience here, and incipient voyeurism. Elkin charmingly confides his ignorance of woman:

the male worker refrains from reasons of courtesy and delicacy from enquiring into some aspects of a woman's life. He is not a physician.

40 Spencer in Gunn 1947:7, from the Argus 21 December 1905.

41 Elkin in Kaberry 1939:xvii-xxxi. 


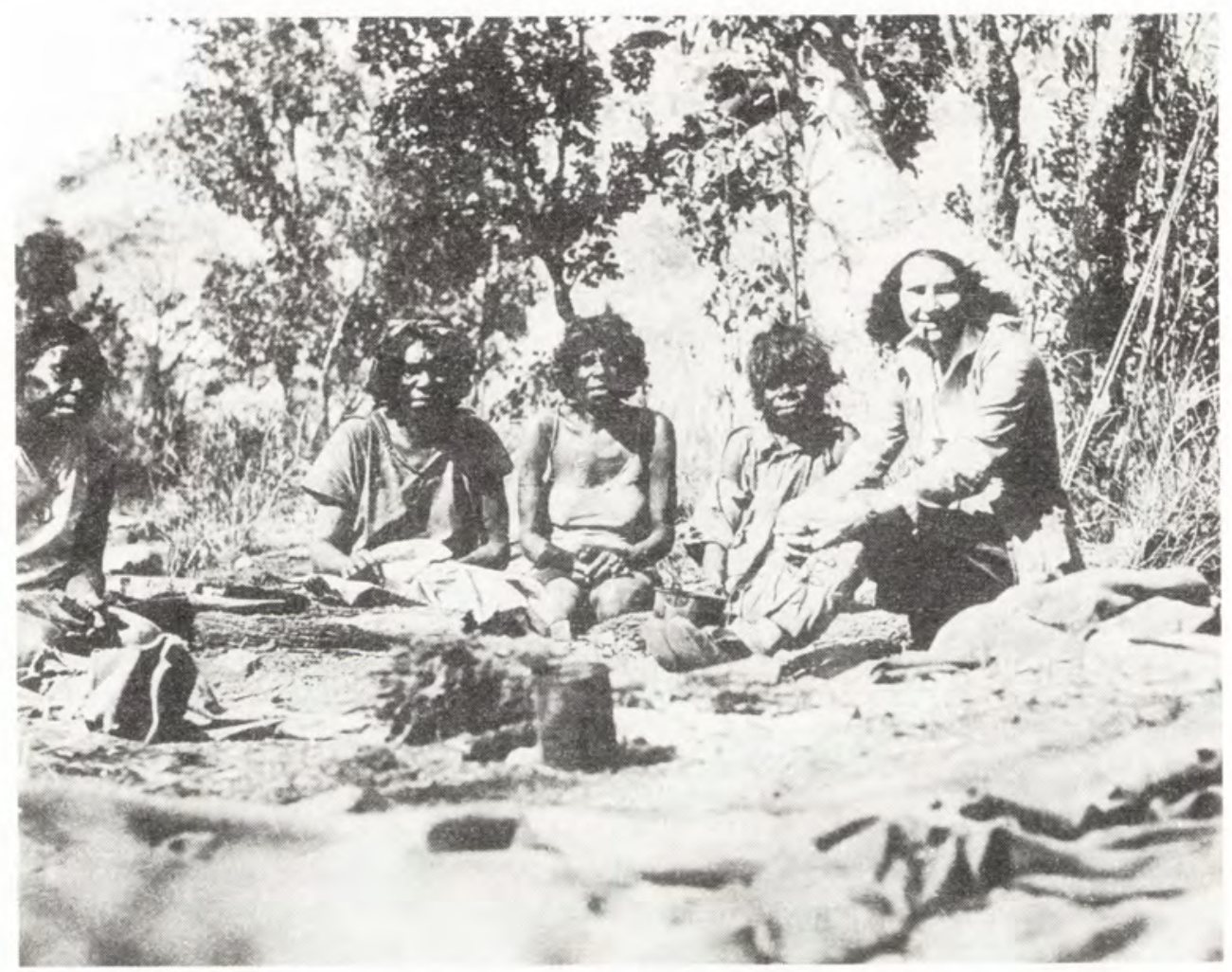

Phyllis Kaberry with Aboriginal women, Kimberleys c. 1937 (Private Collection)

Aboriginal women had a gynaecological rather than a cultural identity. Female sexuality, like the desert country, was uncharted territory. Kaberry had set herself the task of mapping this unknown in an attempt to write Aboriginal women into the realm of the sacred. ${ }^{42}$

The novel in the twentieth century continued to be the main site for the female discourse on marriage and morality. Some years before Kaberry began her pioneering research in the north-west, Katherine Susannah Prichard had journeyed there in search of Aboriginal metaphors for her fiction. Coonardoo, a novel about good and bad marriages serialised in the Bulletin in 1928, found its tragedy in the conflict between the repressed sexuality of the whites and the 'natural' sexuality of Aborigines. It is in this novel that the failures of the good fella missus first come under scrutiny. Before turning to Coonardoo, it is important to know how closely Katharine Susannah Prichard's writing career conforms to the pattern of literary production we have traced so far.

42 Letters from Kaberry to Durack 1935-1939, private collection. I am grateful to Dame Mary Durack for her generous assistance. 


\section{THE LEGEND OF THE GOOD FELLA MISSUS}

Prichard began writing a serial for New Idea in 1906, 'Letters from the Back of Beyond', taking the form of monthly letters from a young governess to her mother! Her first novel, The pioneers (1915), was a saga of frontier life. Prichard fits exactly into the tradition of female fiction that began in Australia with Catherine Helen Spence and Louisa Atkinson. Her central subject was, like theirs, what it meant to be female in a country that offered new opportunities for work and pleasure. The good fella missus of Coonardoo is a bush heroine who had been a school teacher, married a drover, and who, as a widow, managed her cattle station with wisdom and courage - shades of Mrs Dougherty in Gertrude the emigrant girl. Atkinson's first novel was also first published serially, and when their books appeared in volume form, both authors felt a preface was necessary to disabuse readers of their misconceptions. The novels come from life but they are also works of the imagination. The characters are not drawn from real people. Atkinson wrote, 'far too sacred are the affairs of her neighbours to the writer of Gertrude to be rudely brought before the public and bartered for gain'. ${ }^{43}$ Explicit in her preface, and implicit in Prichard's, is that the Aboriginal characters are drawn from life; Atkinson must 'borrow from nature' to truthfully depict this 'peculiar nationality'; Prichard tells us she approached the Chief Inspector of Aborigines for Western Australia to verify her 'drawing of aborigines and conditions' in their 'natural state', and not, as her audience might know them, as the 'poor degraded and degenerate creatures [in] contact with towns and the vices of white people'. ${ }^{44}$ While her Bulletin readers objected that Prichard idealised the Aborigines, the real controversy of Coonardoo was that the plot turned on the white hero's repressed desire and unspoken love for a black woman, and that one of the main characters was a 'swaggering gin-shepherder'.

The exploitation of black women raised by Chisholm in the 1840 s did not become a political issue again until the late 1920s. In Western Australia a school teacher at the Mount Margaret mission, Mary Bennett, documented the conditions of black women from her own observations, from court cases, and from government reports. In the backblocks white men could boast of having a 'fresh native girl every week'. ${ }^{45}$ Feminist groups in the cities called unsuccessfully upon the mercy of the Federal Government to appoint Women Protectors of Aborigines in central and northern Australia. In the 1930s, Olive Pink repeatedly brought the problem to the attention to her fellow anthropologists in Sydney, before she left the profession disillusioned with its inefficacy. 46

Prichard's good fella missus, Mrs Bessie, will have no white stockmen working with her Aborigines, and she steadfastly refuses to entertain the gin-shepherder, Sam Geary. When he visits on business, his women remain outside the home at the woodheap. Mrs Bessie observes with strict attention the boundaries between white and black lives. In the mornings, the Aboriginal women she has trained as servants wash and dress before they cross the verandah, and they returned to their camp in the evenings. She prides herself on not interfering in their tribal lives and will have no Christianising of them.

Although she had lived and worked like a man, so long in the Nor'-West without the least respect for conventional ideas which hampered her in anything she wanted to do, her white woman's prejudices were still intact.

\footnotetext{
43 L. Atkinson 1857:preface.

44 Prichard 1956:foreword.

45 Bleakley quoted by Bennett 1930:113.

46 Nolan 1962:46-48; Olive Pink Correspondence 1932-54, Elkin Papers, Fisher Library, University of Sydney.
} 


\section{ABORIGINAL HISTORY $1990 \quad 14: 2$}

'Mrs Besie had fits of loathing of the blacks'; she knew of this 'singing to make a woman business, as she called it, and did not like it'.

She was disgusted by practices she considered immoral until she began to understand a difference to her own in the aboriginal consciousness of sex. She was surprised then, to find in it something impersonal universal, of a religious mysticism.

It is of course Prichard who wants to uncover a more sacred idea of female sexuality than that diseased idea offered by her own society. In the novel, it is her Coonardoo who is being sung a woman, and Prichard has Mrs Bessie recall a glimpse of this ceremony:

Wandering along the far side of the creek once, she had come on a half-circle of men squatted before a little girl, and singing to her breast. They looked as if they were worshipping her, squatted there on the wide plains under the bare blue sky. And they were in their own way, she imagined, venerating the principle of creation, fertility, growth in her.

Here it is the men who 'worship' her, and in Prichard's fiction, male and female symbols are constructed as opposites and complementaries: active and passive, fire and water, insemination and sustenance. Marriage and motherhood remain the ultimate destiny of woman. Coonardoo is the well in the shadows of a harsh and unforgiving male landscape. She has none of the ambivalence of Prichard's white heroines, but rests secure in her wordless acceptance of a phallomorphic world. It is the white man's repression, the repression that Hugh has inculcated from his mother, that destroys her.

Even deeper and more unconquerable than the silence on the sexual exploitation of black women is the taboo against white women as objects of the black male gaze. In the records, black velvet is always female; Aboriginal men were feared as rapists, yet half-castes always have black mothers. Apart from the white women lost to Aboriginal society on the frontiers in the first decades of settlement, I have come across only one instance of a white woman living black in over a century of writing. She appears in Ernestine Hill's first collection of traveller's tales, The great Australian loneliness (1945). Married to an Aborigine, her name is Mrs Forbes, but Hill prefers to call her Mrs Witchetty. Hill was as bewildered by Mrs Witchetty's choice of Aboriginal life as the sterling mothers had been that Aborigines proved so reluctant to exchange their culture for civilisation. Of all the 'hair-raising thrillers' to be found in unknown Australia, the story of Mrs Witchetty takes the cake. 47

If women in Victorian ideology were the slaves of their husbands, in the twentieth century, after Freud, they were the slaves of their sexuality. Freud himself had drawn on the work of Spencer and Gillen to support his thesis in Totem and taboo (1913). Relying on a similar construct of the Australian Aborigines as living primitives in The elementary forms of religious life (1915), Durkheim argued that men are concerned with the sacred, women with the profane. It was this mythic devaluation and ghettoisation of female life that Kaberry wanted to explode. Like Margaret Mead, she contrasted her findings to her own society. Her analysis of marriage and divorce in Aboriginal woman, sacred and profane reads like a resume of the themes of female fiction - what is a good marriage and what, for a woman, does independence mean? The Aboriginal women Kaberry met in the north-west were much more assertive than Prichard's characters.

Kaberry has left us an image of the white observer of Aboriginal life. This comes in her chapter, "The Duties of Women in Marriage'. Writing that 'women, on their side, were equally tenacious of their rights, and if the husband persisted in his infidelity, they might

Hill 1945:271-275. 


\section{THE LEGEND OF THE GOOD FELLA MISSUS}

leave him permanently', she describes a quarrel that breaks out when one woman accuses her mate of being unfaithful:

Barudjil, in the heat of the argument, picked up his boomerang, banged him, then grabbed a tomahawk to enforce her point... Wanbierin rolled up his swag and departed, hurling obscenities and an occasional boomerang at her, which she avoided easily, but which came unpleasantly near where I was standing diligently making notes.

The conscientious observer is contrasted ironically to her dangerous environment - a contrast between self-control and untrammelled passions; this incongruity is one of the hallmarks of the good fella missus.

In the 1940s painters with political aesthetic convictions similar to Prichard's, like the German emigre expressionist Elise Blumann in Western Australia and the social realist Marguerite Mahood in Melbourne, revived the Aboriginal portrait genre which female artists had eschewed since the nineteenth century (Georgiana McCrae had painted a miniature of her Aboriginal female servant as early as the 1840s). Elizabeth Durack continued to work in a related vein in the 1950 s and 1960s. More important than the renewed interest amongst painters in Aboriginal subjects in the modern period, however, was the appropriation of Aboriginal forms. Margaret Preston is often cited as the first painter to take Aboriginal art seriously on an aesthetic level. Her education was, I would argue, something like Prichard's. Like a good modernist she turned to the Sydney Museum for its reserves of an art that was both abstract and representational. Later at Berowra she sought out the rock carvings along the coast and the carved trees in the hinterland. There was a distinct change in her art and her writings when she travelled north and met living Aboriginal artists. Such was the perverse balance of cultural power in the 1940s that it was commendable for Margaret Preston to paint in a derivative 'Aboriginal' manner but wrong for Namatjira to paint like a white artist.

The type of the Good Fella Missus reached its most fantastic proportions in the diminutive figure of Daisy Bates. She came to Australia as an emigrant girl aspiring to marry into the squattocracy. She went droving and mustering, accompanying her husband like a man, but it proved a bad marriage. Bates became a journalist in London and returned to Australia to make a study of the controversial treatment of Aborigines by the Western Australian government. In the epigraph to her findings Bates quoted Florence Nightingale: 'Can we civilize these people without killing them?' Her ambition to become a professional anthropologist was thwarted by Radcliffe-Brown. ${ }^{48}$ She retreated to central Australia - the desert was a cheap place to live - and began to promulgate the myth about herself as the grandmother of the tribes that congregated at Ooldea, a traditional meeting place on a trade route, near a fresh-water spring. Here she made her camp, drawing a circle around it through which only she and the tiny bush creatures she loved could cross. From her lookout, she charted the passage of the stars, trying to fit them to the Aboriginal stories she was told.

48 White 1980; see also White 1985:introduction. 


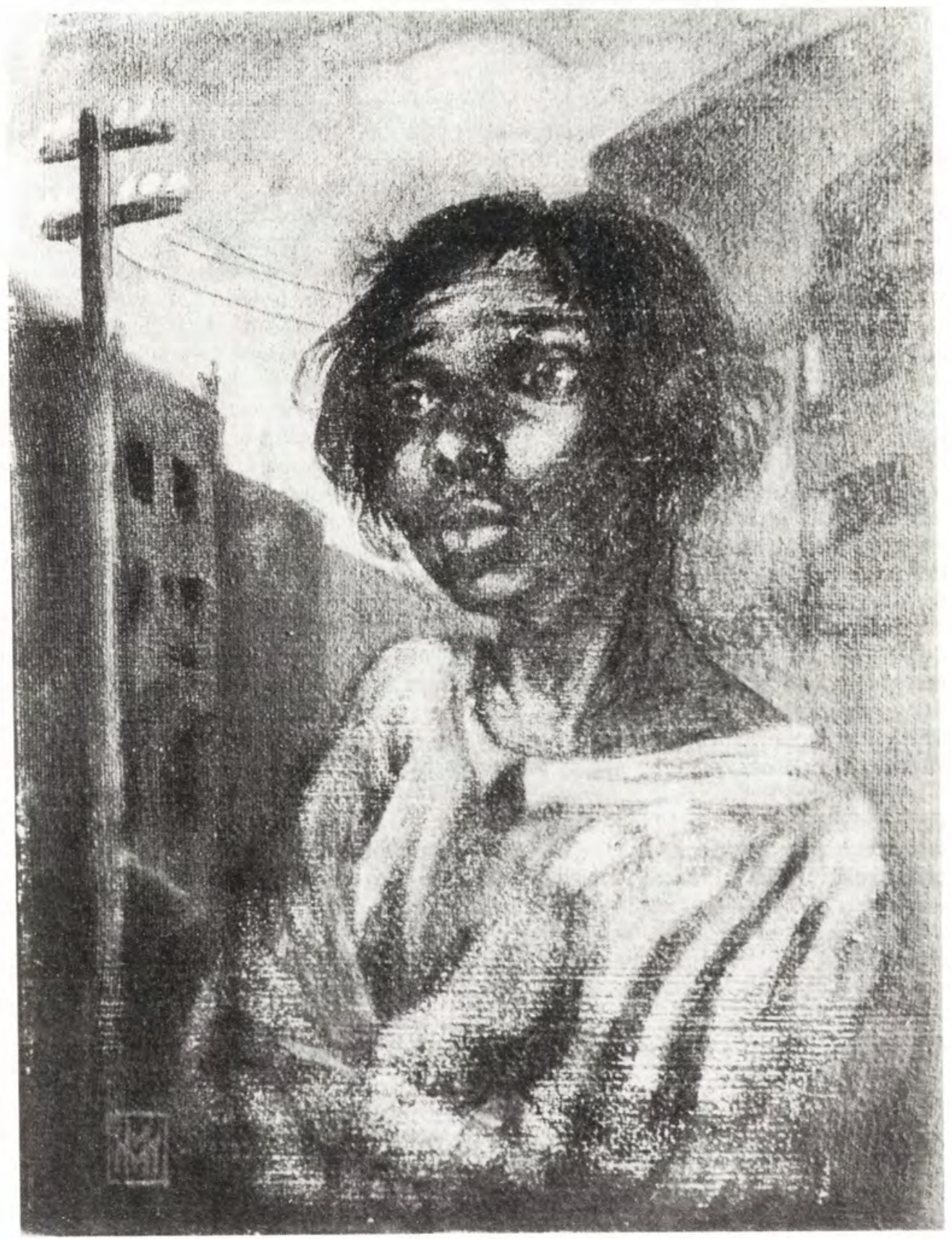

Marguerite Mahood, 'Aboriginal girl', 1942. Courtesy Mr Martin Mahood. 


\section{THE LEGEND OF THE GOOD FELLA MISSUS}

Here she learnt to name the flora and fauna, and to track and hunt. In her tent, she had her volumes of Dickens, and she would read with a mixture of fear and amusement his caricatures of eccentric old women. Bates became what she feared.

Each day Bates would dress formally and cross into the Aboriginal world. She became as notorious as the Aborigines along the transcontinental line. She was the only woman in the country who publicly lived alone with adult blacks. She would write only of 'fullbloods', because 'half-castes' filled her with horror as the ill-begotten fruits of miscegenation. She tended the sick and clothed the naked; she counted on her fingers the last of the tribes. Her serial, 'My Natives and I', published in Brisbane's Courier-Mail and in the Adelaide Advertiser, became the best-seller The passing of the Aborigines (1944). The subtitle of this book is less often quoted: 'A lifetime spent among the natives of Australia'. She was her own heroine and she knew where her model lay, as the article 'Our pioneer women and our natives' (1936) indicates:

Think of it! I am thinking now of real live women who were not afraid, whose daughters were old when they told me the tales their mothers had told them of wild, savage sortees ending in quiet tea-drinkings... Great stress has always evoked just those qualities of steadfast endurance, which are characteristic of our race, but my mind ever rests on their influence with the natives. $^{49}$

\section{Conclusion}

The legend of the good fella missus died with Daisy Bates just after World War II. That the fiction enjoys period revivals only indicates the power and attraction of this myth in white society, despite the ample witness of past and present Aboriginal women and men to the contrary. While there are important differences between the three generations, and while some of the individual women cited are praiseworthy for challenging the ignorance and racism of their society, what matters here is the continuity of the supremacy of the Good Fella Missus. Her hallowed status in Australian history must be dismantled, and the dark side with Aborigines illuminated. Only then perhaps will we find a balance between the horror and the good in the relationship between white women and Aboriginal society.

\section{BIBLIOGRAPHY}

Alford, Katrina. Production or reproduction? An economic history of women in Australia, 17881850. Melbourne, 1984.

[anon.]. A book of South Australia: women in the first hundred years. 1936.

[Atkinson, Louisa]. Gertrude, the emigrant girl: A tale of colonial life, by an Australian lady. Sydney, 1857.

Atkinson, James. An account of the state of agriculture and grazing in New South Wales. Sydney, 1975 (1826).

Baldwin Spencer, Walter. 'An appreciation by Professor Baldwin Spencer', in Mrs Aeneas [Jeannie] Gunn, The little black princess, p.7. Melbourne, 1947.

[Barton, Charlotte]. A mother's offering to her children, by a lady long resident in New South Wales. Brisbane, 1979.

Bates, Daisy. 'Our pioneer women and our natives', in A book of South Australia: women in the first hundred years, pp.93-99. Adelaide, 1936.

49 Bates in [anon] 1936:93-99. 


\section{ABORIGINAL HISTORY $1990 \quad 14: 2$}

Bennett, Mary M. The Australian Aboriginal as a human being. London 1930. . A book of South Australia: Women in the first hundred years. Adelaide, 1936.

Brown, Eliza. 'Narrative of journey from York to Champion Bay, Part Two', in Peter Cowan ed., A faithful picture: The letters of Eliza and Thomas Brown, pp.149-152. Fremantle, 1977.

Bundock, Mary. 'Notes on the Richmond Blacks', in Isobel McBryde ed., Records of times past, pp.261-266. Canberra, 1978.

Daley, Louise Tiffany. Men and a river. Melbourne, 1966.

De Sallis, Margaret. Two early colonials. Sydney, 1967.

Donaldson, Ian and Tamsin Donaldson eds. Seeing the first Australians. Sydney, 1985.

Douglas, Mary. Purity and danger: an analysis of the concepts of pollution and taboo. London, 1984.

Dunlop, Eliza Hamilton. The Aboriginal mother and other poems. Canberra, 1981.

Dutton, Geoffrey. White on black. Melbourne, 1974.

Elkin, A.P. 'Introduction', in Phyllis Kaberry, Aboriginal woman, sacred and profane, pp.xviixxxi. London, 1939.

Evans, Ray. ' "Don't you remember Black Alice, Sam Holt?" Aboriginal women in Queensland history', Hecate 8, 1982:6-21.

Farwell, George. Squatter's castle. Melbourne, 1973.

Foucault, Michel. A history of sexuality, vol.I. Harmondsworth, 1976.

Frost, Lucy. No place for a nervous lady. Ringwood, 1984. 'Annie Baxter and her joumal 1834-1868', in Debra Adelaide ed., A bright and fiery troop, pp.29-40. Ringwood, 1988.

Heney, Helen ed.Dear Fanny, women's letters to and from New South Wales, 1788-1857. Canberra, 1985.

Hill, Ernestine. The great Australian loneliness. Melbourne, 1945.

Hunter, Captain John. Historical journal of events at Sydney and at sea, 1787-92. Sydney, 1968.

Kaberry, Phyllis. Letters to Mary Durack, 1935-1939. Private collection. . Aboriginal woman, sacred and profane. London, 1939.

Kerr, Joan. From Sydney Cove to Duntroon. Melbourne, 1982.

Kiddle, Margaret. Caroline Chisholm. Melboume, 1950.

[MacPherson, Ellen]. My experiences in Australia, by A Lady. London, 1860.

McBryde, Isobel ed. Records of times past. Canberra, 1978.

McCrae, Georgiana. Georgiana's journal, edited by Hugh McCrae. Sydney, 1966.

McGrath, Ann. 'Aboriginal women workers in the Northern Territory', Hecate 4, 1978:5-25.

Meredith, Louisa. Notes and sketches of New South Wales. Sydney, 1973.

Millett, Mrs Edward [Janet]. An Australian parsonage or, the settler and the savage in Western Australia. Nedlands, 1980.

Muir, Marcie. Charlotte Barton, Australia's first children's author. Sydney, 1980. My bush book. K. Langloh Parker's 1980s story of outback station life. Adelaide, 1982.

Murray-Prior, Judith. 'Women settlers and Aborigines', Honours Thesis, History Department, University of New England, 1973.

Nightingale, Florence. Form of return sent from England to His Excellency the Governor of Western Australia, 1860. MS 1358A. Mitchell Library, Sydney.

Nolan, Cynthia. Outback. London, 1962.

Pink, Olive. Correspondence, 1932-1954. Elkin Correspondence. MS. Flinders Library Archives, University of Sydney.

Praed, Rosa. My Australian girlhood. London, 1904. London, 1962.

Prichard, Katharine Susannah. Coonardoo: The well in the shadow. Sydney, 1956.

Smith, Bernard. European vision and the South Pacific. Oxford, 1960. . The spectre of Truganini. Sydney, 1980.

Society for the Propagation of the Gospel in Foreign Parts. Quarterly Paper xxxiii, April 1845. Spender, Dale. Writing a new world. London, 1988.

Stow 'Langloh Parker', Katherine. Letter to A.G. Stephens dated 30 January [1896]. MS A364. Mitchell Library, Sydney. 


\section{THE LEGEND OF THE GOOD FELLA MISSUS}

Thomas, Daniel ed.Creating Australia, two hundred years of art 1788-1988. Adelaide, 1988.

Watts, Jane. Family life in South Australia. Adelaide, 1890.

White, Isobel. 'Mrs Bates and Mr Brown', Oceania 51, 1980:193-210.

'Introduction', in Daisy Bates, The native tribes of Western Australia, pp.1-25. Canberra, 1985. 